\title{
Trichohepatoenteric Syndrome: Founder Mutation in Asian Indians
}

\author{
U.H. Kotecha S. Movva R.D. Puri I.C. Verma \\ Center of Medical Genetics, Sir Ganga Ram Hospital, New Delhi, India
}

\section{Key Words}

Dysmorphism • Founder Mutation • Gujarat • Hair changes • India $\cdot$ Liver hemangiomas $\cdot$ Phenotypic diarrhea .

Syndromic diarrhea

\begin{abstract}
Trichohepatoenteric syndrome (THES) is characterized by chronic diarrhea, dysmorphic facies and hair abnormalities. Hepatic involvement varies from no abnormality to cirrhosis and hemochromatosis. Recently, mutations in the tetratricopeptide repeat domain 37 (TTC37) gene were identified to cause THES. The c.2808G $>$ A variation was suggested as a possible founder mutation among the South Asians. We further report 2 unrelated cases of Asian-Indian ethnicity (Gujrati) with THES, wherein targeted mutation analysis revealed the same mutation in homozygous form in both cases. These findings, as well as haplotype analysis, corroborate the founder mutation hypothesis amongst Asian Indo-Pakistani ethnic groups. A restriction enzyme-based method is also described to identify this founder mutation. One of our probands had multiple hepatic hemangiomas, a feature not previously observed in this syndrome.
\end{abstract}

Copyright ๑ 2012 S. Karger AG, Basel
(C) 2012 S. Karger AG, Basel

1661-8769/12/0032-0089\$38.00/0

Fax +41613061234

E-Mail karger@karger.ch

www.karger.com
Accessible online at:

www.karger.com/msy
Intractable diarrhea in patients with phenotypic abnormalities or syndromic diarrhea was first described by Stankler et al. [1982]. Many cases have since been reported and presently both trichohepatoenteric syndrome (THES) and syndromic diarrhea are considered as the same entity [Fabre et al., 2007]. THES is characterized by chronic diarrhea, hair abnormalities, hepatic involvement, immunodeficiency and facial dysmorphism. While phenotypic variability is known, chronic diarrhea and hair abnormalities are constant features [Barabino et al., 2004]. In 2010, the tetratricopeptide repeat domain 37 (TTC37) gene on chromosome 5 was identified as the causative gene for THES [Hartley et al., 2010]. Recently, genetic heterogeneity in THES has been documented, with causative mutations in SKIV2L gene [Fabre et al., 2012]. The study by Hartley et al. [2012] included a total of 11 patients of whom 6 were of Asian origin. Homozygous c. $2808 \mathrm{G}>\mathrm{A}$ mutation was detected in 3 unrelated Asian patients with the same haplotype and was proposed as a probable founder mutation in South Asian patients. Here we report 2 cases of Asian-Indian origin with the same mutation, and similar haplotype, further corroborating the founder mutation hypothesis. We also describe a restriction enzyme analytic method for diagnosis of this mutation. 


\section{Clinical Reports}

\section{Patient 1}

The proband, a 3-year-old boy, third in birth order, was born at term to a nonconsanguineous Gujarati couple. His birth weight was $2,000 \mathrm{~g}$ (<3rd centile). He was exclusively breast fed for 6 months during which time he remained asymptomatic. At onset of weaning around 6 months of age, he developed diarrhea, with passage of 15-20 semisolid to watery, yellowish, non-foul smelling stools. The frequency increased after feeding, but there was no correlation to any specific diet. There also was no symptomatic relief of diarrhea, even after eliminating gluten and lactose from the diet. There was no accompanying fever, vomiting, abdominal distention, or blood in stools.

He was hospitalized in the past for lower respiratory tract infections. He exhibited a delay in motor milestones as he was not walking independently even at the age of 3 years. An older sister had died with similar features at 2.5 years of age but without a definitive diagnosis in spite of extensive investigations.

$\mathrm{He}$ had failure to thrive with weight at $8 \mathrm{~kg}(<3 \mathrm{rd}$ centile), length of $82 \mathrm{~cm}(<3 \mathrm{rd}$ centile) and head circumference of $57 \mathrm{~cm}$ (5-50th centile). He had dysmorphic features with a prominent forehead, depressed nasal bridge and prominent cheeks. His hair was sparse, easily pluckable and depigmented (fig. 1). Microscopic examination of the hair showed a discontinuous shaft with areas of thinning and breaks (fig. 2). Six hyperpigmented, café-aulait spots, varying in size between 1 and $5 \mathrm{~mm}$, were present over the abdomen and thighs. There were no signs of protein and vitamin deficiency. There was no hepatosplenomegaly, and the examination of other organ systems was normal.

The proband was extensively investigated for the cause of diarrhea. The stool sample was positive for reducing substances and fat globules. However, the $72 \mathrm{~h}$ quantitative fecal fat estimation was normal. Concentration of chloride measured by the sweat chloride test was normal ( $16 \mathrm{mE} / \mathrm{l})$. The IgA tissue transglutaminase level was not increased. Enzyme and metabolite analysis excluded galactosemia. Screening for inborn errors of metabolism by tandem mass spectrometry and urine organic acid analysis was normal. Serum levels of zinc, iron, ferritin, total iron binding capacity, and vitamin B12 were normal. HIV serology was negative. There was an isolated elevation in SGPT level (497 IU/l), which returned to baseline levels, when repeated after 12 months. Renal functions tests, serum immunoglobulin levels and flow cytometric analysis of T lymphocytes (CD3, CD4 and CD8 subtypes) were normal.

Gastric biopsy showed atrophic gastritis with mild foveal hyperplasia and mild chronic inflammatory infiltrate in the lamina propria. Duodenal biopsy was suggestive of normal villous architecture with increased cellularity in lamina propria.

\section{Patient 2}

The patient is the first child of a nonconsanguineous Gujarati couple. He was born at 35 weeks gestation with a birth weight of $1,500 \mathrm{~g}$ (3-10th centile). Congenital heart disease (atrial septal defect, muscular ventricular septal defect and patent foramen ovale) and multiple hepatic hemangiomas were detected in the neonatal period. The hemangiomas gradually regressed in size on ultrasound studies. At 5 months of age, weaning had been initiated with fruit juice; followed by recurrent secretory diarrhea and failure to thrive. On examination at 11 months of age, he was

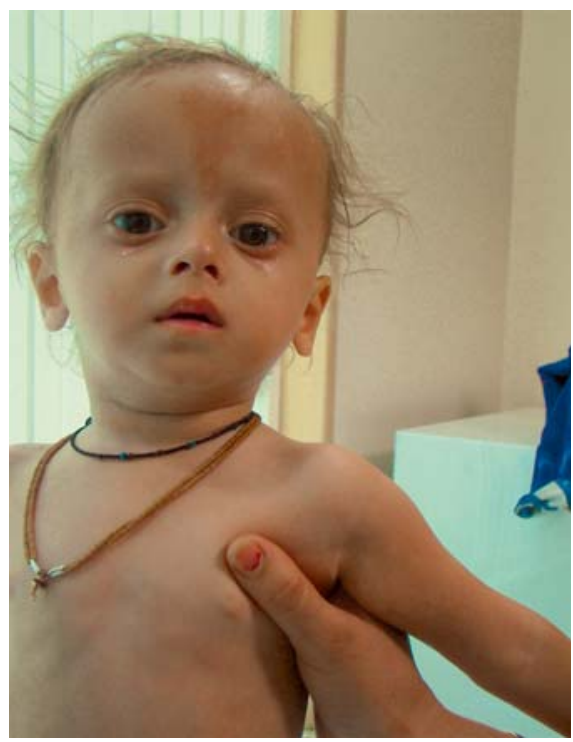

Fig. 1. Dysmorphic facial features of patient 1.

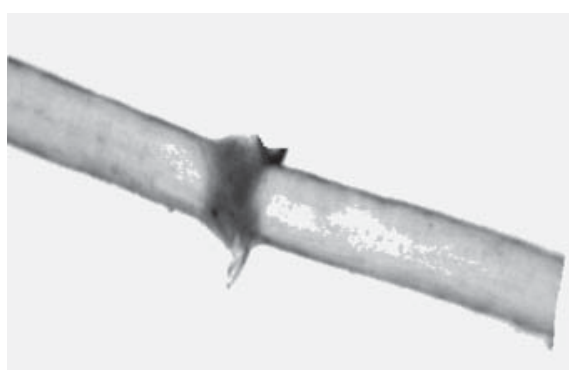

Fig. 2. Light microscopic examination of the hair of patient 1 .

noted to have facial dysmorphism (prominent forehead, depressed nasal bridge, sparse, easily pluckable hair, but no café-aulait spots). The liver was palpable, $4 \mathrm{~cm}$ below costal margin, firm in consistency with a well-defined margin. Liver biopsy showed chronic hepatitis with cirrhosis and an increase in copper content $(150 \mu \mathrm{g} / \mathrm{g})$. Intestinal mucosal biopsy suggested duodenitis with marked villous atrophy. Laboratory investigations for common causes of chronic diarrhea, as in case 1, were normal.

The above features suggested a possible diagnosis of trichohepatoenteric syndrome. Molecular analysis was carried out to confirm the clinical diagnosis.

\section{Methods}

TTC37 gene consists of 43 exons with no currently known hot spots [Fabre et al., 2011]. Sequencing of all 43 exons is expensive, and economic constraints in developing countries necessitate a reorientation for alternative methods. Hence, we first decided to 
Fig. 3. Inverted figure of Ethidium bromide stained 2\% Agarose gel showing TTC37 c.2808G $>$ A gene mutation after digestion with Hinf1 restriction enzyme and the chromatogram with altered sequence.

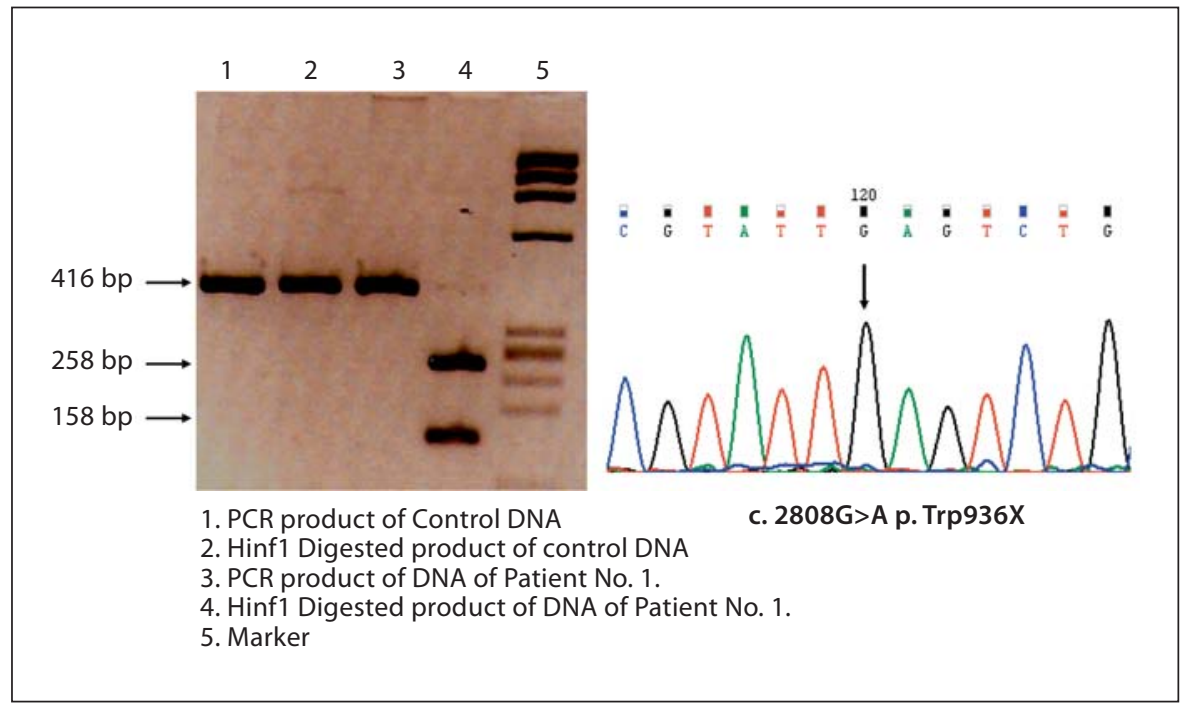

check for the recurrent South Asian mutation (c.2808G $>$ A) in exon 28 of TTC37 gene [Hartley et al., 2010]. Using New England Biolabs (NEB cutter) tool, we identified the restriction enzyme Hinf1 (GANTC), which recognizes the altered base and cleaves the exon 28 fragment of $416 \mathrm{bp}$ to give 2 fragments of $258 \mathrm{bp}$ and $158 \mathrm{bp}$.

DNA from both patients was isolated from peripheral blood using standard methodology. A 3-step PCR, using previously published primers for amplification of exon 28 [Hartley et al., 2010], was carried out to obtain a 416 bp product. The amplified product was digested with Hinf I restriction endonuclease (Fermentas, Canada). Haplotype analysis using the markers rs255375 and rs34897 was carried out in the 2 probands. Fifty normal patients of Gujrati origin were tested for this mutation by the restriction enzyme method.

\section{Results}

On RFLP analysis, 2 fragments of 258 and 158 bp were obtained in both patients, thus confirming the presence of the mutation c.2808A (fig. 3). These observations were verified by bidirectional sequencing of the PCR product. The parents were identified to be heterozygous for the mutation by sequencing. Apart from c.2808G $>$ A mutation, no other variation was seen after sequencing exon 28 .

To estimate the prevalence of the $\mathrm{c} .2808 \mathrm{G}>\mathrm{A}$ variation in the Indian population, 50 normal individuals from Gujarat state were analyzed for the c.2808G $>$ A by Hinf 1 restriction enzyme. All of them were found to be homozygous for the normal GG genotype.

To verify the founder mutation (c.2808G $>$ A) hypothesis, as suggested by Hartley et al. [2010] in the 3 patients of Indo-Pakistani origin, haplotype analysis was carried out in our cases for the single nucleotide polymorphisms, rs255375 and rs34897, spanning over a 974-kb region containing TTC37 gene. Both the cases were homozygous for the marker rs34897. However, for the marker rs255375, case 1 was homozygous, while case 2 was heterozygous. These findings support the founder mutation hypothesis.

\section{Discussion}

The estimated frequency of trichohepatoenteric syndrome is 1 in 400,000-500,000 live births [Goulet et al., 2008]. It is characterized by a triad of diarrhea, dysmorphism and hair changes. The clinical features observed in our 2 patients are compared with those in other patients that have been published in table 1 . The diarrhea can occur as early as 2 weeks, though it is more common after 4-5 months of age. Surprisingly, although the diarrhea is intractable, intestinal biopsy of all reported patients to date (including ours) suggests a nonspecific villous atrophy. Recent molecular studies have helped in explaining this paradox as the gene TTC37 has been shown to affect the localization of apical transport proteins in the jejunum [Hartley et al., 2010]. Despite its name, hepatic involvement in THES is reported to be variable, ranging from no abnormality to hemochromatosis and cirrhosis [Dwekait et al., 2007, Fabre et al., 2011]. Hepatic hemangiomas observed in case 2 have not been previously reported. The same child also had a congenital heart disease, a feature which was first described by Hartley et al. [2010]. 
Table 1. Comparison of clinical findings with reported cases

\begin{tabular}{|c|c|c|c|c|c|c|c|c|c|c|c|c|}
\hline & $\begin{array}{l}\text { Stankler } \\
{[1982]}\end{array}$ & $\begin{array}{l}\text { Girault } \\
{[1994]}\end{array}$ & $\begin{array}{l}\text { Verloes } \\
\text { [1997] }\end{array}$ & $\begin{array}{l}\text { de Vries } \\
{[2000]}\end{array}$ & $\begin{array}{l}\text { Schroeder } \\
{[2003]}\end{array}$ & $\begin{array}{l}\text { Barabino } \\
{[2004]}\end{array}$ & $\begin{array}{l}\text { Dweikat } \\
\text { [2007] }\end{array}$ & $\begin{array}{l}\text { Fabre } \\
\text { [2007] }\end{array}$ & $\begin{array}{l}\text { Egritas } \\
\text { [2009] }\end{array}$ & $\begin{array}{l}\text { Hartley } \\
\text { [2010] }\end{array}$ & $\begin{array}{l}\text { Fabre } \\
{[2011]}\end{array}$ & $\begin{array}{l}\text { Current } \\
\text { study }\end{array}$ \\
\hline Number of patients & 2 & 8 & 2 & 1 & 1 & 1 & 1 & 2 & 1 & 12 & 9 & 2 \\
\hline Preterm birth & 2 & 4 & 2 & 1 & no & no & no & 1 & 1 & 8 & 2 & 1 \\
\hline IUGR & 2 & 8 & 2 & 1 & 1 & 1 & no & 2 & 1 & 10 & 7 & 2 \\
\hline Diarrhea & 2 & 8 & 2 & 1 & 1 & 1 & 1 & 2 & 1 & 12 & 9 & 2 \\
\hline Villous atrophy & $\begin{array}{l}\text { biopsy not } \\
\text { done }\end{array}$ & 3 & 1 & 1 & 1 & 1 & $\begin{array}{l}\text { biopsy not } \\
\text { done }\end{array}$ & 1 & no & yes & 6 & 2 \\
\hline Dysmorphism & 2 & 8 & 2 & 1 & 1 & 1 & 1 & 2 & 1 & 12 & 9 & 2 \\
\hline Hair anomaly & 2 & 8 & 2 & 1 & 1 & 1 & 1 & 2 & 1 & 12 & 9 & 2 \\
\hline Café-au-lait spots & none & none & none & none & none & none & none & none & none & 3 & none & 1 \\
\hline Immunodeficiency & 1 & 8 & no & 1 & 1 & 1 & no & 1 & no & yes & 9 & 1 \\
\hline $\begin{array}{l}\text { Developmental } \\
\text { delay }\end{array}$ & $\begin{array}{l}\text { death at } 33 \\
\text { and } 87 \text { days } \\
\text { of life }\end{array}$ & 3 & absent & mild & 1 & 1 & $\begin{array}{l}\text { death at } 10 \\
\text { months, } \\
\text { normal } \\
\text { development } \\
\text { till then }\end{array}$ & 1 & absent & 7 & $5 / 8$ & 2 \\
\hline
\end{tabular}

Table 2. Differential diagnosis of trichohepatoenteric syndrome

\begin{tabular}{|c|c|c|c|c|c|c|}
\hline & $\begin{array}{l}\text { Microvillous } \\
\text { inclusion disease }\end{array}$ & Tufting enteropathy & $\begin{array}{l}\text { Congenital sodium } \\
\text { diarrhea }\end{array}$ & $\begin{array}{l}\text { Congential chloride } \\
\text { diarrhea }\end{array}$ & Menkes disease & $\begin{array}{l}\text { Trichohepato } \\
\text { enteric syndrome }\end{array}$ \\
\hline Diarrhea onset & $48 \mathrm{~h}-2$ months & few days after birth & perinatal onset & $\begin{array}{l}\text { perinatal to first few } \\
\text { days after birth }\end{array}$ & $\begin{array}{l}\text { variable, } \\
\text { can present as early as } \\
2-3 \text { months }\end{array}$ & 2 weeks -6 months \\
\hline Dysmorphism & absent & present in some & $\begin{array}{l}\text { present in some } \\
\text { (hypertelorism) }\end{array}$ & absent & $\begin{array}{l}\text { present } \\
\text { (fronto-occiptial } \\
\text { bossing, pudgy cheeks, } \\
\text { micrognathia) }\end{array}$ & present \\
\hline Hair changes & absent & absent & absent & absent & $\begin{array}{l}\text { present (steely wool } \\
\text { hair) }\end{array}$ & present \\
\hline Stool examination & normal & normal & $\begin{array}{l}\text { elevated fecal } \\
\text { sodium levels }\end{array}$ & $\begin{array}{l}\text { elevated fecal } \\
\text { chloride }\end{array}$ & normal & normal \\
\hline $\begin{array}{l}\text { Associated } \\
\text { features }\end{array}$ & & $\begin{array}{l}\text { esophageal atresia, } \\
\text { choanal atresia, } \\
\text { imperfoprate anus, } \\
\text { punctate keratitis }\end{array}$ & $\begin{array}{l}\text { esophageal atresia, } \\
\text { choanal atresia, } \\
\text { corneal ulcerations }^{\mathrm{a}}\end{array}$ & $\begin{array}{l}\text { polyhydraminos, } \\
\text { hypochloremia, } \\
\text { metabolic alkalosis }\end{array}$ & $\begin{array}{l}\text { neuroregression, } \\
\text { seizures, failure to } \\
\text { thrive }\end{array}$ & $\begin{array}{l}\text { immunodeficiency, } \\
\text { cafe-au-lait spots, } \\
\text { congenital heart } \\
\text { disease, liver } \\
\text { involvement }\end{array}$ \\
\hline Inheritance & $\begin{array}{l}\text { autosomal recessive, } \\
\text { MYO5B gene }\end{array}$ & $\begin{array}{l}\text { autosomal recessive, } \\
E p C A M \text { gene }\end{array}$ & $\begin{array}{l}\text { autosomal recessive } \\
\text { SPINT2 in } \\
\text { syndromic diarrhea }\end{array}$ & $\begin{array}{l}\text { autosomal recessive } \\
\text { SLC26A3 gene } \\
\text { mutations }\end{array}$ & $\begin{array}{l}\text { X-linked recessive, } \\
\text { ATP7A gene }\end{array}$ & $\begin{array}{l}\text { autosomal recessive, } \\
\text { TTC37 and SKIV2L } \\
\text { gene }\end{array}$ \\
\hline
\end{tabular}

a These findings are seen only in syndromic diarrhea. 
The differential diagnosis of THES includes other causes of autosomal recessive chronic diarrhea like microvillous inclusion disease [Ruemmele et al., 2006] and tufting enteropathy [Goulet et al., 2007]. However, both these conditions are associated with characteristic histological changes, which were absent in our patients (table 2). Similarly, congenital sodium and chloride diarrhea can be diagnosed by elevated fecal levels of sodium [Müller et al., 2000] and chloride [Hihnala et al., 2006], respectively. Mutations in SPINT2 gene are known to cause a syndromic form of congenital sodium diarrhea which is characterized by corneal erosions, choanal or anal atresia and hypertelorism in addition to intractable diarrhea [HeinzErian et al., 2009]. Trichorrhexis nodosa, diarrhea and increased copper content in the liver, all of which were present in case 2, are also observed in Menkes disease [Tümer and Møller, 2010]. However, absence of neurological involvement essentially excludes this X-linked disorder in our patient.

Our findings further endorse homozygous c. $2808 \mathrm{G}>\mathrm{A}$ as a common mutation in the Asian Indian population for THES. Interestingly, both our patients were Gujarati by ethnicity. While the ethnicity of the Indian patient reported by Hartley et al. [2010] is unknown, both the Pakistani patients, who were homozygous for c.2808G $>$ A, were from Mirpur (personal communication from Hartley, 2012). There are 2 Mirpurs in Pakistan, one in Pakistan Occupied Kashmir, whereas the second is Mirpur Khas, which is situated along the border of Gujarat (India). It is not known which of the 2 Mirpurs was the abode of the Pakistani patients described by Hartley et al. [2012], but it is likely that they were from Mirpur Khas which adjoins Gujarat state in India. It is suggested that Gujarat state in India and adjoining areas in Pakistan represent a geographical hot spot for this mutation, which is likely to be a founder mutation. The analysis of the 2 SNPs supports this hypothesis, as one patient was homozygous for the 2 polymorphisms, while the second was homozygous for one (rs34897) and heterozygous for the other polymorphism (rs255375).

We also describe an easy and cheap targeted analysis for this founder mutation and recommend testing using this method as the first step for molecular diagnosis of THES in the Indo-Pakistani subcontinent.

\section{References}

Barabino AV, Torrente F, Castellano F, Frba D, Fabre A, Charroux B, Martinez-Vinson C, Calvi A, Gandullia P: 'Syndromic diarrhea' may have better outcome than previously reported. J Pediatr 144:553-554 (2004).

de Vries E, Visser DM, van Dongen JJ, Jacobs CJ, Hoekstra JH, van Tol MJ: Oligoclonal gammopathy in phenotypic diarrhea. J Pediatr Gastroenterol Nutr 30:349-350 (2000).

Dweikat I, Sultan M, Maraqa N, Hindi T, AbuRmeileh S, Abu-Libdeh B: Tricho-HepatoEnteric syndrome: a case of hemochromatosis with intractable diarrhea, dysmorphic features and hair abnormality. Am J Med Genet A 143:581-583 (2007).

Egritas O, Dalgic B, Onder M: Tricho-hepatoenteric syndrome presenting with mild colitis. Eur J Pediatr 168:933-935 (2009).

Fabre A, André N, Breton A, Broué P, Badens C, Roquelaure B: Intractable diarrhea with 'Phenotypic Anomalies' and Tricho-HepatoEnteric syndrome: two names for the same disorder. Am J Med Genet A 143:584-588 (2007).

Fabre A, Martinez-Vinson MC, Roquelaure B, Missirian C, André N, et al: Novel mutations in TTC37 associated with tricho-hepato-enteric syndrome. Hum Mutat 32:277-281 (2011). Roquelaure B, Odul E, et al: SKIV2L mutations cause syndromic diarrhea, or trichohepatoenteric syndrome. Am J Hum Genet 90:689-692 (2012).

Girault D, Goulet O, Le Diest F, Brousse N, Colomb V, et al: Intractable diarrhea associated with phenotypic abnormalities and immunodeficiency. J Pediatr 125:36-42 (1994).

Goulet O, Salomon J, Ruemmele F, Serres NP, Brousse N: Intestinal epithelial dysplasia (tufting enteropathy). Orphanet J Rare Dis 2: 1-20 (2007).

- Goulet O, Vinson C, Roquelaure B, Brousse N, Bodemer C, Cézard JP: Syndromic (phenotypic) diarrhea in early infancy. Orphanet J Rare Dis 3:6 (2008).

Hartley JL, Zachos NC, Dawood B, Donowitz M, Forman J, et al: Mutations in TTC37 cause trichohepatoenteric syndrome (phenotypic diarrhea of infancy). Gastroenterol 138: 2388-2398 (2010).

-Heinz-Erian P, Müller T, Krabichler B, Schranz $\mathrm{M}$, Becker C, et al: Mutataions in SPINT2 cause a syndromic form of congenital sodium diarrhea. Am J Hum Genet 84:188-196 (2009).

- Hihnala S, Höglund P, Lammi L, Kokkonen J, Ormälä T, Holmberg C: Long-term clinical outcome in patients with congenital chloride diarrhea. J Pediatr Gastroenterol Nutr 42: 369-375 (2006).
Landers MC, Schroeder TL: Intractable diarrhea of infancy with facial dysmorphism, trichorrhexis nodosa and cirrhosis. Pediatr Dermatol 20:432-435 (2003).

- Müller T, Wijmenga C, Phillips AD, Janecke A, Houwen RH, et al: Congenital sodium diarrhea is an autosomal recessive disorder of sodium/proton exchange but unrelated to known candidate genes. Gastroenterol 119: 1506-1513 (2000).

Ruemmele F, Schmitz J, Goulet O: Microvillous inclusion disease (microvillous atrophy). Orphanet J Rare Dis 1:5 (2006).

-Stankler L, Lloyd D, Pollit RJ, Gray ES, Thom H, Russell G: Unexplained diarrhea and failure to thrive in 2 siblings with unusual facies and abnormal scalp hair shafts: a new syndrome. Arch Dis Child 57:212-216 (1982).

Tümer Z, Møller BL: Menkes disease. Eur J Hum Gen 18:511-518 (2010).

Verloes A, Lombet J, Lambert Y, Hubert AF, Deprez M, et al: Tricho-Hepato-enteric syndrome: further delineation of a distinct syndrome with neonatal hemochromatosis phenotype, intractable diarrhea and hair abnormalities. Am J Med Genet 68:391-395 (1997). 